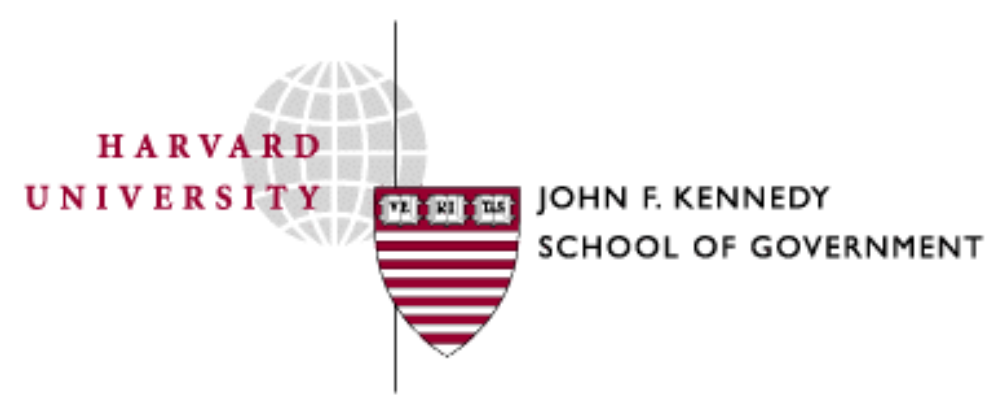

Faculty Research Working Papers Series

\title{
Global Imbalances and Low Interest Rates: An Equilibrium Model vs. a Disequilibrium Reality
}

\author{
Jeffrey Frankel \\ John F. Kennedy School of Government - Harvard University
}

August 2006

RWP06-035

This paper can be downloaded without charge from: http://ksgnotes1.harvard.edu/Research/wpaper.nsf/rwp/RWP06-035

or

The Social Science Research Network:

http://ssrn.com/abstract=902385

The views expressed in the KSG Faculty Research Working Paper Series are those of the author(s) and do not necessarily reflect those of the John F. Kennedy School of Government or Harvard University. Copyright belongs to the author(s). Papers may be downloaded for personal use only. 


\title{
Global Imbalances and Low Interest Rates: An Equilibrium Model vs. a Disequilibrium Reality
}

Comments in response to the paper by Ricardo Caballero, Emmanuel Farhis \& Pierre-Olivier Gourinchas

\author{
Jeffrey Frankel \\ Harpel Professor of Capital Formation and Growth \\ Harvard University
}

\author{
BIS Annual Research Conference \\ Brunnen, Switzerland, June 19-20, 2006
}




\section{Introduction}

Caballero, Farhis \& Gourinchas (2006) are motivated by three current properties of the world financial system:

- Fact 1: US current account deficits are large and rising.

- Fact 2: Long-term interest rates have been low since 2002.

- Fact 3: The share of US assets in world portfolios has been rising. Fact 3 follows naturally from fact 1; Fact 2 is the real anomaly.

The C, F \& G model is a tour-de-force. It shows how all three properties could be the outcome of an equilibrium situation. The model features three regions: a highgrowth high-finance " $U$ " zone (US, UK, Australia), a low-growth high-finance " $E$ " zone (the euro area plus Japan), and a high-growth low-finance " $R$ " zone (the rest of world). The model is fully developed. I like the assumption that only a certain fraction $\delta$ of future income can be capitalized into tradable financial assets, and that this varies with the quality of countries' institutions. I like too that the authors build up the model step by step:

- Small county

- 2-countries: $U \& E$

- 2 countries: $U \& R$

- 3 countries.

The paper allows for various other parameter shifts and extensions, including (importantly) investment slumps \& FDI (part 3).

The basic idea is that "fast growth in $R$ [essentially emerging markets] coupled with their inability to generate local store of value instruments increases their demand for saving instruments from $U$ and $E$. More growth potential in $U$ than in $E$ means that a larger share of global saving flows to $U$ " (p. 4). The model would indeed account for the three facts, if true. It is driven by the combination of (i) a hypothesized collapse in capacity of $R$ to generate attractive assets, and (ii) a growth slowdown in the $€$-zone and Japan. These disturbances fit the 1990s fairly well. My one concern, however, is that they don't fit 2003-2006 as well, which is the puzzle period, that is, the period that featured the record US current account deficits coinciding with low long-term interest rates. Emerging markets have had a high capacity during 2003-06 to generate assets that others want (in contrast to the crises of the late 1990s). I would say $\delta_{R}$ today is above where it was in the 1980s, not below. Even the economies of Japan and Germany have recently recovered from their decade-long slumps.

I won't try to do the model justice in the rest of my comments. Instead, I will review the topic of the global imbalances -- mainstream view vs. dissenters -- before locating CFG in this space of viewpoints.

Figure 1 (1960-2005) illustrates the alarming rate at which the US trade and current account balances are deteriorating. 
Figure 1

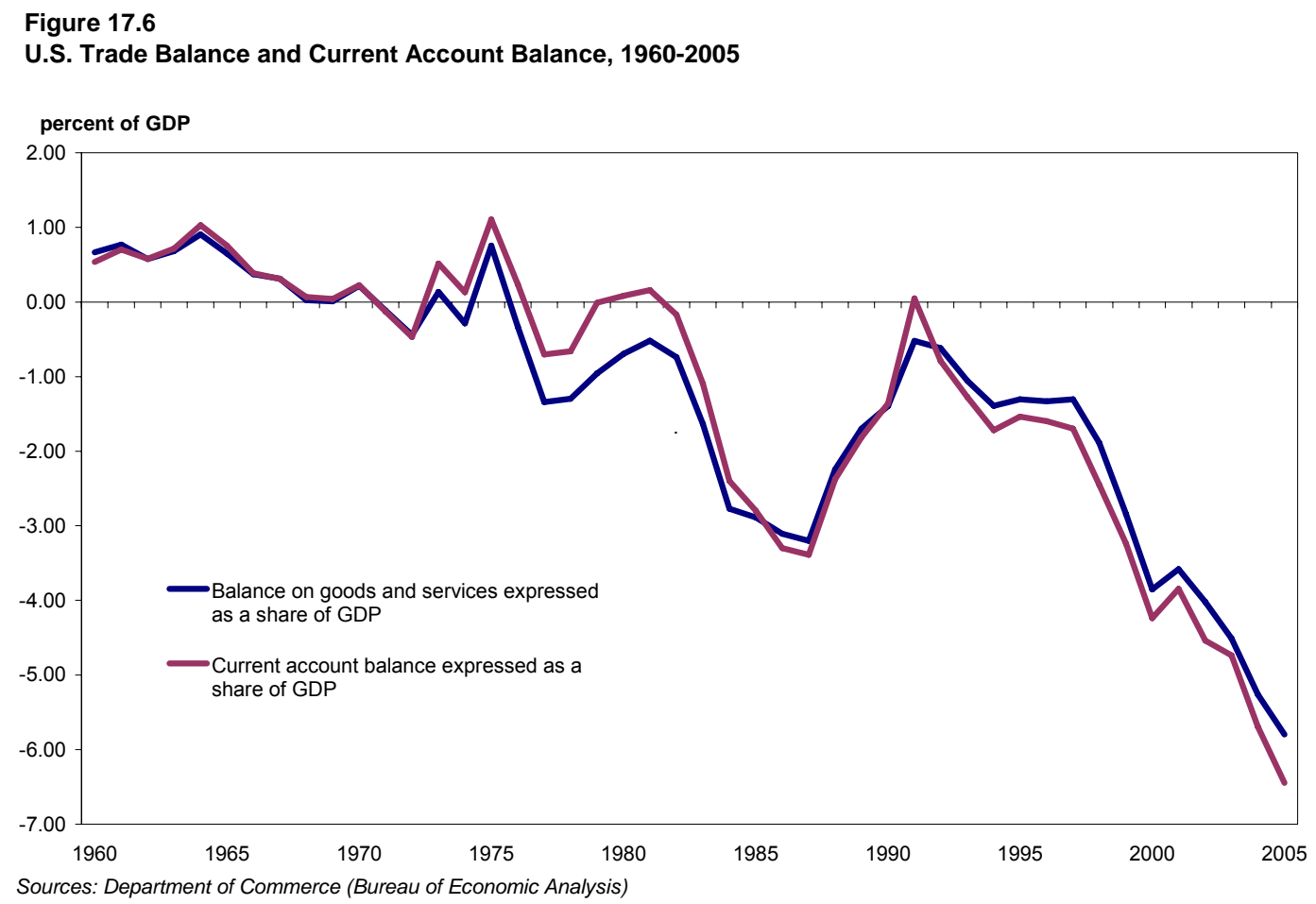

The US deficits hit record levels in 2005: $6 \frac{1}{2} \%$ GDP for the current account deficit. It seems likely to hit 7\% likely in 2006 . These levels would set off alarm bells in Brazil, Turkey or South Africa. There are likely harmful effects in the short, medium, and long terms: The short-term danger is protectionism in the US Congress, which has taken the form of scapegoating China for our problems. The medium-term danger is a hard landing for the dollar, stemming from the rising dependence on foreign investors to finance the deficits. The long-term danger, from the viewpoint of Americans, stems from the high net debt to the rest of the world, now at about $\$ 3$ trillion and still far from signs of reaching a plateau. To service this debt, America's grandchildren will suffer a reduced standard of living. Furthermore, dependence on foreign central banks may eventually bring about a loss of US global hegemony.

In Figure 2, reproduced here from the authors' paper, holdings of US assets by foreigners have risen, whether measured relative to the size of the world portfolio or, especially, relative to world output, both of which can be thought of as relevant for the world's ability to absorb dollar assets. If we were talking about about any other country, the denominator would be a measure of US ability to pay, such as US output or US exports or US output of tradable goods -- not a measure of the rest-of-the-world's ability to absorb. Empirically, the relevant determinant of the ability to pay turns out to be a trade measure like exports plus imports, not GDP - relevant in the sense that the 
ratio of trade to GDP is a good statistical predictor of immunity against sudden stops and currency crashes in a broad sample of countries: Cavallo \& Frankel (2005). It is not good news for the US economy, which has a low X/GDP ratio. Indeed this is the basis on which Obstfeld \& Rogoff $(2001,2005)$ have been warning for a number of years that the US eventually faces an abrupt, disruptive, and large depreciation of the dollar. If one computes foreign indebtedness as a ratio of exports, rather than as a fraction of the world portfolio, then the current US path is explosive.

Figure 2

Share of US Assets in Rest of the World's Output and Financial Wealth

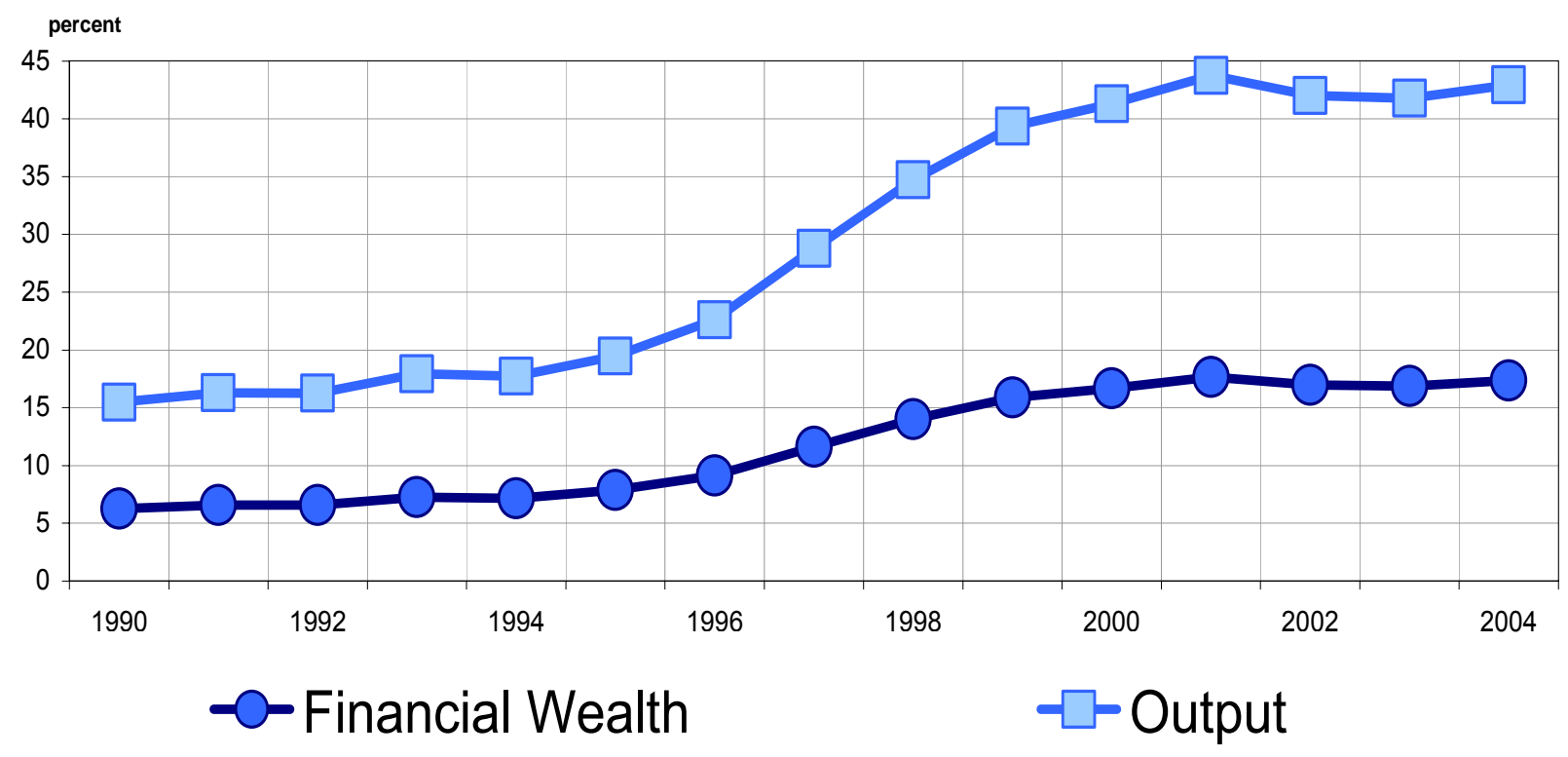

Source: Caballero, Farhi and Gourinchas (2006) 
The remainder of my comments will attempt to bring some further perspective, by reviewing two sides of the debate over the global imbalances. First, I will summarize the "twin deficits" or "US saving shortfall" view of the origins of the US current account deficit, which regards it as unsustainable. I used to call this the mainstream view, but it has received so many challenges -- only a few of them coming from apologists for the current US government -- that I must acknowledge that the dissenters may outnumber the purveyors of the "conventional wisdom." Second, I will review the most popular challenges, most of which suggest that the US current account deficit is nothing to worry about. Caballero, Farhas and Gourinchas seem to fit in this second view.

\section{The "Mainstream" View: A Shortfall of National Saving in the US}

According to the "Mainstream" view, the US current account fundamentally reflects a shortfall in National Saving: the rapid widening of the US CA deficit in early 1980s, and again at an accelerated rate during 2001-05, were both associated with strong declines in National Saving as Figure 3 shows.

Figure 3. Net National Saving, Investment, and Current Account as Shares of GDP

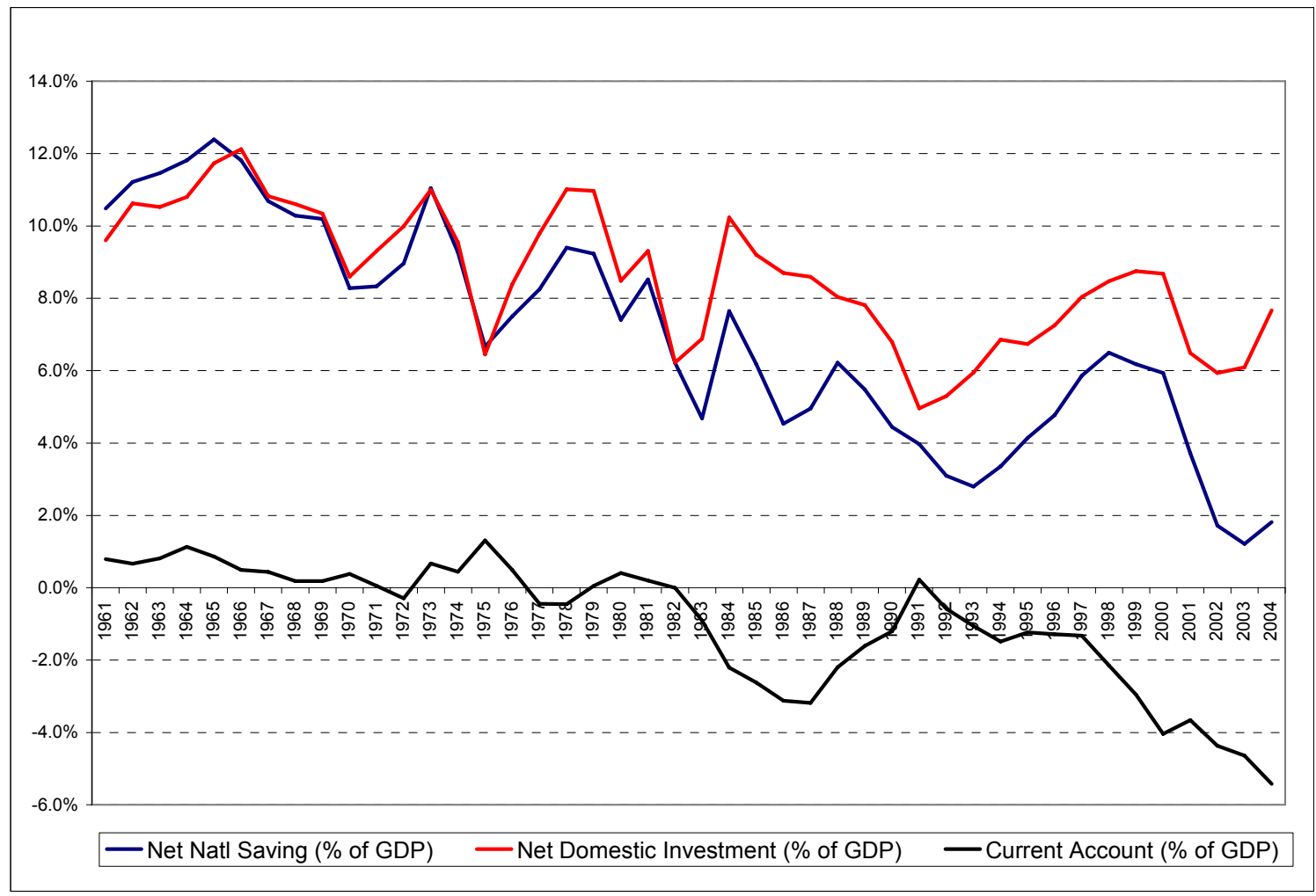


True, trade deficits are affected by such determinants as exchange rates and growth rates at home and abroad. But these are just the "intermediating variables." The CFG paper notes perceptively: "the view that growth of US trading partners is on average similar to that of the US, so that differential growth cannot be a factor in explaining the large capital flows to the US is misguided from our perspective....If those that compete with the US in asset production grow slower and those that demand assets grow faster, then both factors play in the same direction." (p. 6).

More fundamentally, the US trade deficit reflects a shortfall in National Saving. When the US current account deficit widened rapidly in the early 1980s and again when the deterioration accelerated sharply in 2001-06, both events were associated with strong declines in National Saving.

Why did National Saving fall in these episodes? Start with the numbers. Both times, in the early 1980s and 2001-06, the federal budget balance fell abruptly. In the first episode it deteriorated from a deficit that averaged 2\% of GDP in the 1970s, to a peak of 5\% in 1983. In the second episode it swung from a 2000 surplus of $2 \%$ GDP, to deficits around 3\% of GDP in 2003-2004. According to some theories, pro-capitalist tax cuts were supposed to have resulted in higher household saving. But both times, saving actually fell after tax cuts. U.S. household saving is now close to or less than zero ! Thus both components of US National Saving fell.

What was the cause of the decline in National Saving? The Bush Administration has, since it assumed office in 2001, enacted large tax cuts, together with rapid increases in government spending. There are parallels not only with the Reagan Administration in the early 1980s, but also with the Johnson Administration in the late 1960s:

- Big rise in defense spending

- Rise in non-defense spending as well

- Unwillingness of president to raise taxes to pay for it.

- Resulting decline in the trade balance

- Eventual gradual decline in global role of the dollar.

In the Johnson episode, the subsequent decline in the role of the dollar took the form of the end of the US commitment to accept dollars in exchange for gold and eventually, in 1971, the end of the Bretton Woods system under which countries pegged to the dollar. In the second episode, the twin deficits probably contributed to a continued decline throughout the 1980s in the share of central banks' reserve portfolios allocated to dollars and the rise of the share of the yen and mark. Meanwhile, efforts by German and French leaders to supply a new international currency that would be stable in value since the US seemed no longer able to do so eventually bore fruit, first in the form of the European Monetary System, and then in the form of the euro.

The current bout of American fiscal irresponsibility is actually worse than the 1980s. First, the retirement of the baby boom generation is that much closer than it was in 1981. Second, the national debt is that much higher. Third we now have other new fiscal time bombs as well, e.g., phony sun-setting of tax cuts, the annual need to fix the Alternative Minimum Tax (AMT), and an exacerbated Medicare shortfall. The current administration seems to lack ability -- which the Reagan Administration and the elder 
Bush did have -- to perceive when reality diverged from the speech-writers' script, and to respond with mid-course correction. To the contrary, the White House continues to propose more tax cuts. Further, after a transitory dip, the much more serious deterioration will start after 2009 (although the 10-year window is no longer reported in White House projections). The cost of tax cuts truly explode in 2010, if they are made permanent as the Administration wants, as does the cost of fixing the AMT. The baby boom generation starts to retire in 2008; this implies soaring costs of social security and, especially, Medicare.

This "mainstream view" - that the shortfall in national saving is the primary driver - must contend with the conundrum of why long-term interest rates have been so low since 2001. (Figure 4 shows the flattening of the US yield curve.) Indeed the tension between these two phenomena was the stimulus for the Caballero, Farhis and Gourinchas paper.

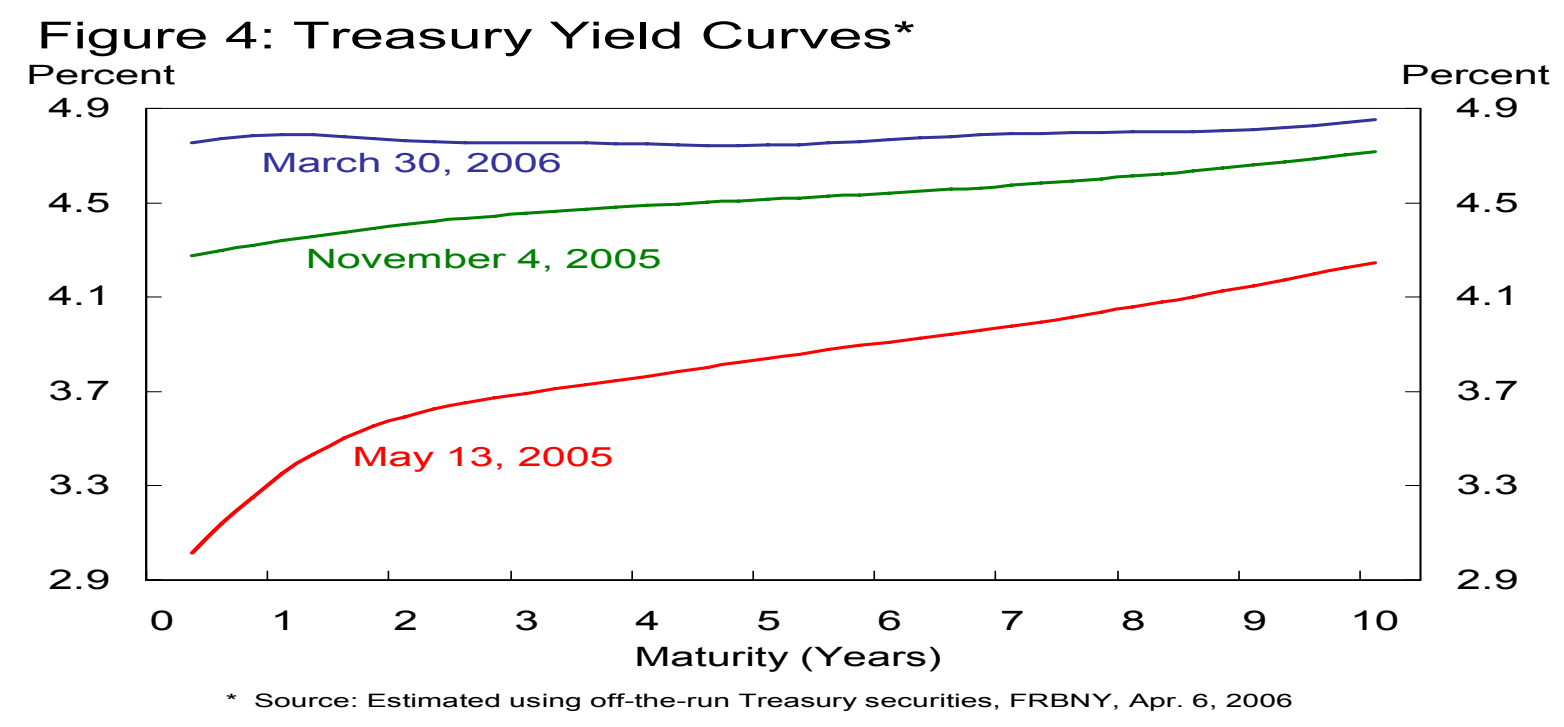

In my view, three major factors kept long-term interest rates low in the first half of this decade. The first was easy monetary policy by the Federal Reserve Board, the European Central Bank (less so), the Bank of Japan (more so), and the People's Bank of China. One can see, in the authors' figure 5, globally low short-term interest rates since 2001 pulling down the long-term real rate. Low short-term rates have led to the "carry trade:" money has gone into bonds, stocks, real estate, emerging markets, and commodities - anywhere that it might be earn a higher return than the very low rates that were on offer in the US and Japan. The period of easy monetary policy has been coming to an end. Indeed, in the US case, the Fed began raising short-term interest rates in mid2004. Why was there no reversal in the bond market and other markets over the subsequent two years? Bubbles were a possible candidate explanation. Often in financial markets, for a year or two after fundamentals have turned around, prices have kept moving under the own momentum, until the markets notice the lack of support, at which point they come crashing down (the 1985 dollar, 1990 Japanese stock market, 
1995 yen, and 2000 US stock market). Attributing unexplained movements to "bubbles" is not an attractive approach for an academic economist. But since many of the markets in question did indeed begin to correct in 2006, one must consider the possibility that the correction was a delayed reaction to the tightening of monetary policy, notwithstanding that the delay does some violence to our notions of well-functioning financial markets.

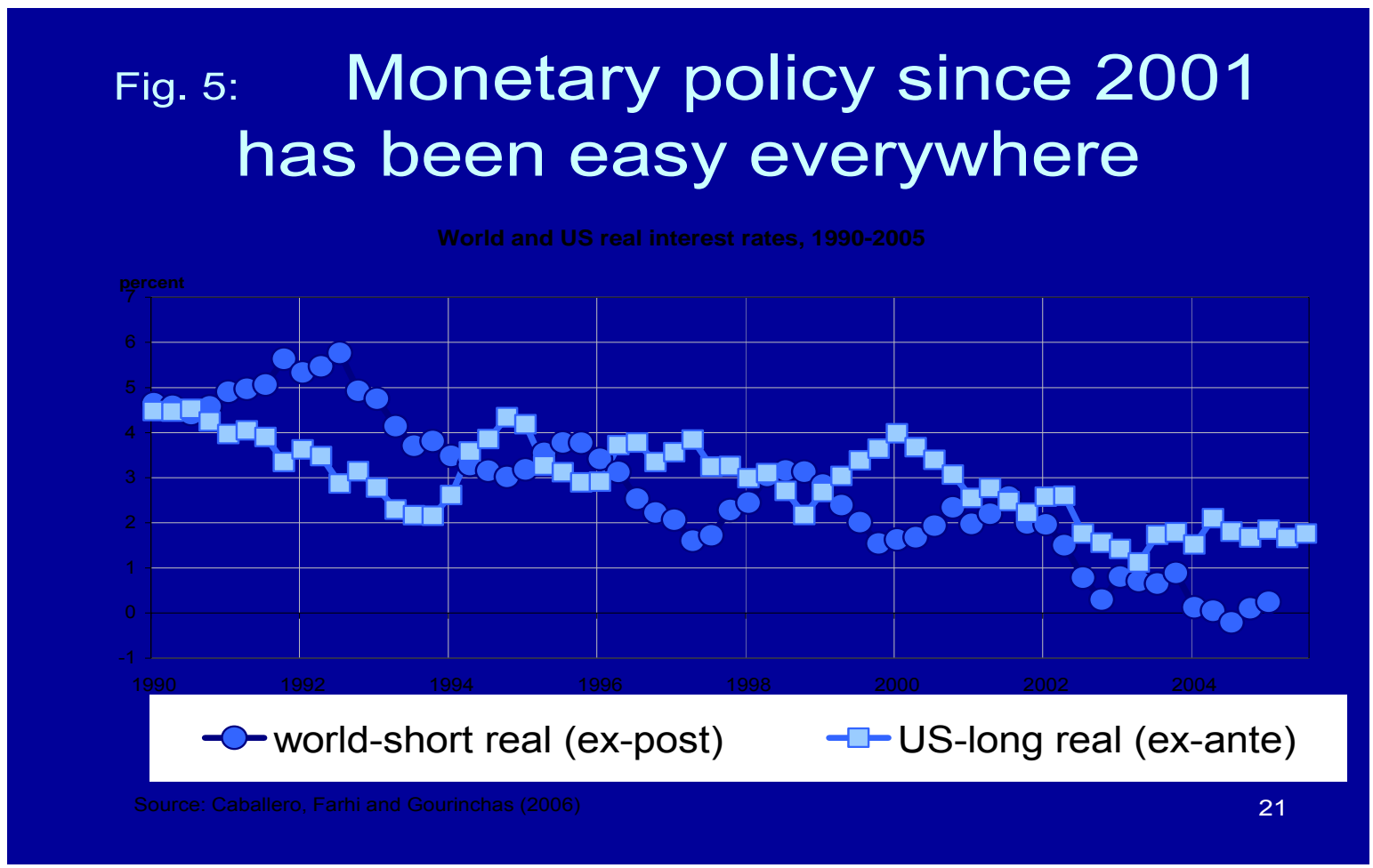

The second factor that has kept US long-term interest rates low in the first half of the decade was foreign central banks doing the same thing that the Fed was doing: buying US securities. The third factor is that investors have not yet fully understood how bad is the long run fiscal outlook in the United States (and in Europe and Japan as well).

All three factors are probably coming to an end soon. On this basis, one ventures to forecast further rises in long-term interest rates, even beyond what has happened between 2005 and 2006 . 


\section{Why We Are Not Supposed To Worry: Eight Challenges to the Mainstream View}

Caballero, Farhis and Gourinchas are on a list of economists - by now rather long -who have come up with ingenious arguments why we shouldn't worry about the US deficits. Indeed the list is so long that one can probably no longer apply the label "mainstream" or "conventional wisdom" to the view that the source of the US current account deficit is an unsustainable shortage of US national saving.

I count eight distinct arguments against the twin deficits view, and in favor of the view that the current account deficit is sustainable and not a cause for worry.

1. The siblings are not twins

2. Alleged investment boom

3. Low US private savings

4. Global savings glut

5. It's a big world

6. Valuation effects will pay for it

7. "Intermediation rents...pay for the trade deficits"

8. China's development strategy entails accumulating unlimited dollars

Ultimately I don't buy these arguments. But it is well worth going through the list.

\section{1. "The 'twin deficits' view is wrong, because the budget and current account deficits do not always move in lockstep." ${ }^{1}$}

This is a "straw man." Use of the term "twin deficits" does not mean to claim that current account and budget deficits always move together, and nobody pretends that they do. Of course the budget deficit and current account deficit can and do at times move in opposite directions, as in the US investment boom of 1990s. The claim, however, is that in the 1980s and the current decade, U.S. fiscal expansion led to both the budget deficit and the current account deficit.

\section{Capital is flowing to the US due to its favorable investment climate and consequent high return to capital.}

It should be easy to dispose of this argument. In the first place, the current US business investment rate is less than it was in the 1990s IT boom (or 60s, 70s, \& 80s). In the second place, FDI is flowing out of the US not in. (Where is it flowing to?

Developing countries like China. ${ }^{2}$ ) In the third place, the money coming into the US is

\footnotetext{
${ }^{1}$ Bernanke (2005) is one of many making this point.

${ }^{2}$ The flow of FDI out of the US and into China - not directly, at it happens, but let us say indirectly, via other OECD countries -- is consistent with Part 3 of the CFG paper. How does it square with inferior property rights in the non OECD world in their model?
} 
largely purchases of short-term portfolio assets, especially acquisition of dollar forex reserves. The importance of foreign official purchases of dollars rose steadily from 2001 to 2004. (See table.) Many observers have accepted at face value the official US statistics that show the rate of purchases declining somewhat in 2005 and 2006. But there are good reasons to think that central banks in Asia and now, especially, among oilexporting countries may be adding to their dollar holdings in ways that do not show up in the US data as foreign official purchases, such as via European financial centers.

\begin{tabular}{|c|c|c|c|c|c|}
\hline \multicolumn{6}{|c|}{$\begin{array}{l}\text { Table 6: Foreign central banks finance an } \\
\text { increasing share of the US current account deficit }\end{array}$} \\
\hline & $\begin{array}{l}\Delta \text { foreign } \\
\text { priv. assets } \\
\text { in US }\end{array}$ & $\begin{array}{l}\Delta \text { US private } \\
\text { assets abroad }\end{array}$ & $\begin{array}{l}\text { Net priv. } \\
\text { capital } \\
\text { inflow }\end{array}$ & $\begin{array}{l}\Delta \text { Foreign } \\
\text { official US } \\
\text { assets * }\end{array}$ & $\begin{array}{l}\text { Official } \\
\text { share of } \\
\text { inflow }\end{array}$ \\
\hline 2000 & 1004 & 559 & 445 & 43 & 0.09 \\
\hline 2001 & 755 & 377 & 378 & 28 & 0.07 \\
\hline 2002 & 678 & 291 & 387 & 116 & 0.23 \\
\hline 2003 & 611 & 330 & 281 & 278 & 0.5 \\
\hline 2004 & 1046 & 860 & 186 & 395 & 0.68 \\
\hline 2005 & 1072 & 513 & 559 & 221 & 0.28 \\
\hline $\begin{array}{c}\text { Billions } \\
\text { Source }\end{array}$ & $\begin{array}{l}\text { of dollars. } \\
\text { US BEA \& Treasury }\end{array}$ & * Increasingly, foreign & CBs' purchases & of $\$$ are not recorded & as such. 26 \\
\hline
\end{tabular}

\section{A fall in US private saving has been as big a part of the fall in national saving as has been the budget deficit.}

This is true. But recall that Bush tax cuts were supposedly designed to be prosaving: abolition of the estate tax, sharp reductions in taxes on dividends \& capital gains, and so forth. That was the excuse for their regressivity. As the private saving rate did not subsequently rise, this is a further indictment of our current fiscal policy. The same characterization applies to the Reagan tax cuts of 1981: they were supposed to boost saving but were instead followed by a fall in US private saving rates (let alone national saving rates).

Some recent papers suggest that if one allows countries to vary not only according to the development of their financial institutions but also according to a property rights parameter, once can explain the pattern of FDI flowing in at the same time that portfolio capital is flowing out. See Ju and Wei (2006) and the papers cited there. 


\section{4. "The problem is a global savings glut, not a US saving shortfall." 3}

True, foreign net lending to US is determined by conditions among foreign lenders as much as in US. But the term "savings glut" is highly misleading: Global saving is not really up. ${ }^{4}$ The case of Japan, which was not long ago feared for its superhuman saving rate, is striking: the household saving rate has lately been $7 \%$ of disposable income, down from $23 \%$ in 1975 . Rather than a rise in foreign saving being the driver, it is global investment is way down. One could call this an $R$ investment slump, as in CFG. But in any case the pattern is inconsistent with the hypothesis that the exogenous change underlying the flow of capital to the US is an increase in saving abroad: that would have shown up as an international rise in investment. The observed pattern is consistent, rather, with the hypothesis that the US shortfall is sucking in capital from rest of world.

\section{5. "It's a big world."}

The argument here is that world financial markets are big, relative even to the $\$ 3$ trillion of US debt, and are increasingly integrated. ${ }^{5}$ As a consequence, foreign investors can bail us out for decades. If foreign investors keep moving, even slowly, toward fully diversified international portfolios (away from "home country bias" in their investments), they can absorb US current account deficits for a long time. Once again, this much is true. But, as already noted, when it comes to default or country risk, GDP or exports may be more relevant denominators for debt than is global portfolio size. Debt dynamics suggest that the US Debt/Export ratio is currently on an explosive path.

\section{The US current account deficit does not imply rising debt \& debt-service}

Lane \& Milesi-Feretti (2005) compute valuation effects. As a result of gains in the dollar value of assets held abroad, particularly via dollar depreciation, US net debt has risen "only" to $\$ 3$ trillion, despite much larger increase in liabilities to foreigners. The question then becomes how many times can the US fool foreign investors?

\section{Despite years of deficits, net investment income is still in surplus}

As is well-known, the US earns a higher rate of return on its assets abroad (especially FDI) than it pays on its obligations (especially treasury bills). In the 1960s, Kindleberger (1965) characterized the United States as playing the role of World Banker, taking short-term deposits and investing long-term. Today, Gourinchas and Rey (2005) call US global "venture capitalist." Their chart, which is reproduced here as Figure 6, shows that the composition of US holdings abroad is tilted toward high-return FDI and

\footnotetext{
${ }^{3}$ Again, Bernanke (2005)

${ }^{4}$ True, overall saving/GDP outside US had by 2004 climbed to a level slightly greater that of 1990s. But it is still less than the 1980s, the reference period in the CFG paper. More importantly, investment is down.

${ }^{5}$ This view can be attributed to Richard Cooper (2005) and Alan Greenspan, among others.
} 
equity, and away from low-return debt. Hausmann and Sturzenegger (2006) speak of "dark matter," by which they mean US hidden assets of know-how that are not properly reflected in service export numbers. Cline (2005) calls the US an economic net creditor, though a net international debtor in an accounting sense. But Daniel Gros (2006) figures that the accounting errors are going the other direction, that foreign companies are understating profits of US subsidiaries, probably to avoid taxes.

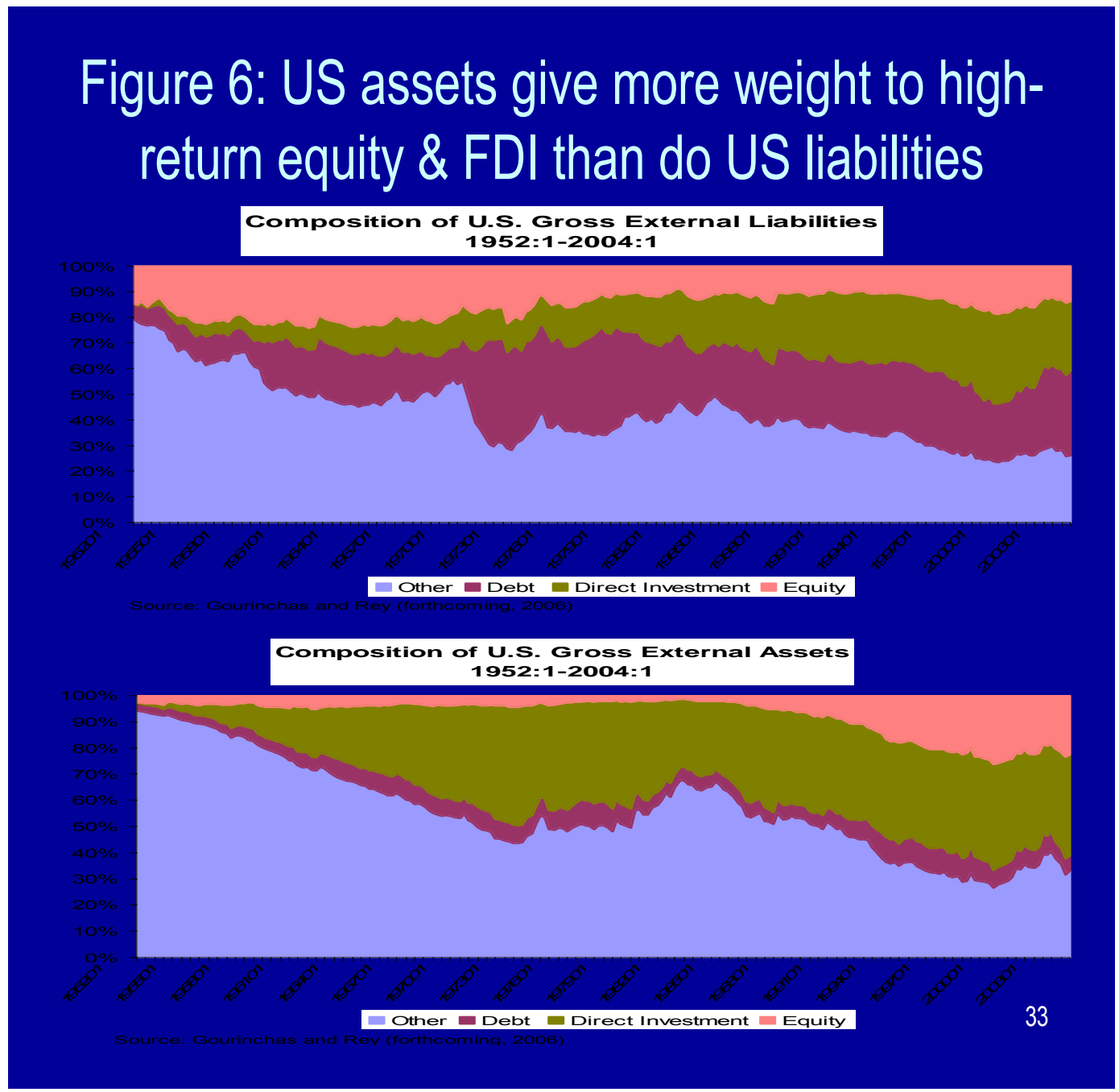

Some of these arguments rely on the dollar retaining its unique role in the world monetary system forever. The French in the 1960s called it the "exorbitant privilege": the rest of the world gives up real goods and companies in exchange for pieces of paper (dollars). The arguments assume that the dollar stays the premier international reserve currency held by central banks, and that the US treasury security market will continue to be the preferred liquid asset for private investors as well. This has been true since World War II, but one can no longer assume that it will necessarily always be true: the euro now exists as a plausible rival over the longer term. 
In a recent paper, Menzie Chinn and I econometrically estimate determinants of reserve currency status: size of home economy, size of its financial markets, inflation rates, exchange rate volatility, trend depreciation, lagged adjustment, and a tipping phenomenon. We conclude that under certain scenarios - roughly either the United Kingdom joining the euro or, more likely, the dollar continuing to lose value in the future at the same rate as it has during 2001-2004 -- the euro could surpass the dollar as leading international reserve currency by 2022. Figure 7 shows the share of the dollar versus the euro in such a simulation. If this tipping took place the cost to the US would probably extend beyond the simple loss of seignorage narrowly defined. We would lose the exorbitant privilege of playing banker to the world, accepting short-term deposits at low interest rates in return for long-term investments at high average rates of return. Global monetary hegemony is a century-long advantage that is not to be cast away lightly.

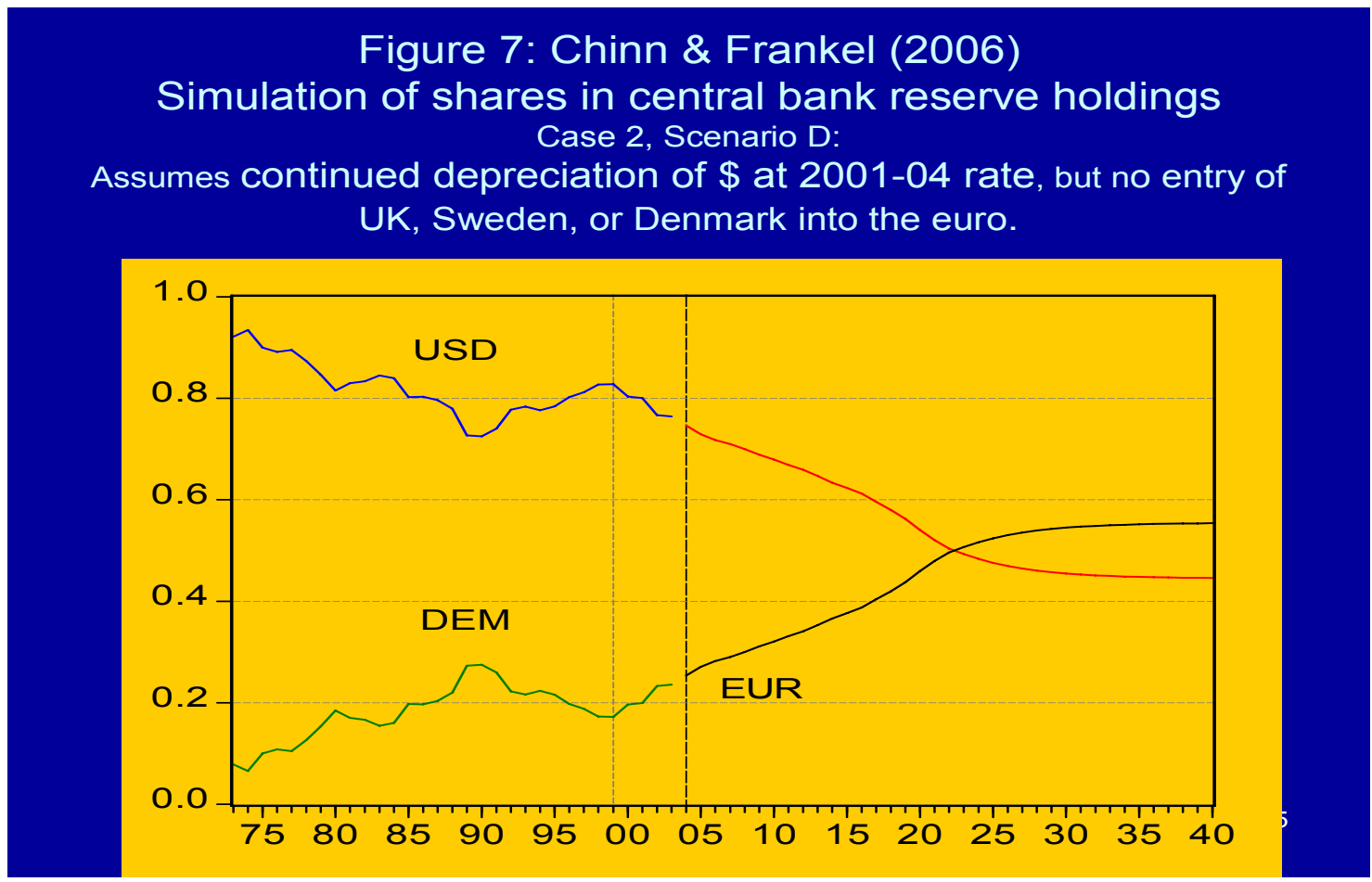

\section{8. “China's development strategy entails accumulating unlimited dollars.”}

The view of Dooley, Folkerts-Landau, and Garber (2003) has received a lot of attention and has come to be associated in the US with their employer Deutschebank. They begin, perceptively enough, with the observation that today's system is a new Bretton Woods, with Asia playing the role that Europe played in the 1960s - buying up lots of dollars to prevent their own currencies from appreciating. Then the authors go on to some more original and provocative ideas: China is piling up dollars not because of myopic mercantilism, but as part of an export-led development strategy that is rational given China's need to import workable systems of finance and corporate governance. 
Initially, they were understood to be saying that this system could continue indefinitely. More recently, they have been pinned down as claiming only that it can go on for ten or 15 years, comparable to the life of the Bretton Woods system. ${ }^{6}$ My own view is that the Bretton Woods analogy is apt, but we are closer to 1971 (the date of the collapse of the Bretton Woods system) than to 1944 (the date of the actual meeting at Bretton Woods, N.H.) or 1958 (when currency convertibility was first restored in Europe). The current situation is more like the 1960s than Dooley, Folkerts-Landau and Garber had in mind. It might have taken decades after 1958 for the Triffin dilemma to work itself out. But the Johnson and Nixon administrations greatly accelerated the process by expansionary fiscal and monetary policies (driven by the Vietnam War and Arthur Burns, respectively). These policies led rapidly to the declining trade balance and overall balance of payments, and the collapse of the Bretton Woods system in 1971 and of the failure of the attempted patch in 1973. There is no reason to expect better today. First, capital mobility is much higher now than in the 1960s. Second the US can no longer necessarily rely on support of the foreign creditor central banks -- neither on economic grounds (they are not now as they were then organized into a cooperative framework where each agrees explicitly to hold dollars if the others do), nor on political grounds (the US is not as popular internationally as we once were). This is all reason to fear that the current imbalances cannot be sustained for very many years.

\section{Caballero, Farhis and Gourinchas}

Where do Caballero, Farhis and Gourinchas fit in? They take as given US comparative advantage in the ability to generate financial assets that others want to hold. This assumption is similar to arguments, under challenge \#7 above, about America's unique good fortune in the form of its ability to serve as World Banker, supplier of intermediation services, owner of \#1 international currency, beneficiary of exorbitant privilege, or recipient of flight to quality. In the words of the authors, "Intermediation rents...pay for the trade deficits." Why is one on firmer ground taking any of these exceptionalisms as exogenously and eternally given, as opposed to considering that the willingness of foreigners to hold dollars may be an unsustainable disequilibrium?

This brings up a question of modeling philosophy or methodology: what to do when the desire to build an Equilibrium Model conflicts with what appears to be a Disequilibrium Reality? When events depart from conventional economics, do you revise the theory, or predict that events will soon fall in line? Sometimes there is a temptation to revise the theory too quickly. I have already mentioned examples of overvalued currencies and stock markets in the United States and Japan that fell back into line a year or two after the fundamentals had turned around. Similarly, the euro was predictably undervalued relative to fundamentals in 2002, and emerging market spreads too low repeatedly in 1981,1996 , and $2005 .^{7} \quad$ In each case new theories - both academic and popular - were invented to rationalize the anomaly, but reality re-asserted itself within a few years.

Perhaps bond markets were simply "too high" (long-term interest rates too low) in 2005. After all, speculators, investors, business economists, talking heads, journalists,

\footnotetext{
${ }^{6}$ Dooley and Garber (2005).

${ }^{7}$ On emerging markets: Rogoff (2004).
} 
politicians, and voters are all adept at thinking up rationalizations for extrapolating whatever has been the current trend. It does not leave much for us academic economists to do if we aren't prepared to stick to our guns - the longer-term perspective of theory, history, and statistics - when markets wander away. Caballero, Farhis and Gourinchas do an elegant job of showing that theory can be adapted to match a conundrum exhibited by the markets over the past few years. But I prefer to continue waiting for the markets to come to me instead.

\section{$\underline{\text { References }}$}

Bernanke, Ben S., 2005, "The Global Saving Glut and the U.S. Current Account Deficit," Remarks by Governor, Sandridge Lecture, Virginia Association of Economics, Richmond, Virginia, March 10.

Caballero, Ricardo, Emmanuel Farhis and Pierre-Olivier Gourinchas, 2006, “An Equilibrium Model of 'Global Imbalances' and Low Interest rates," Bank for International Settlements Annual Research Conference, Brunnen, Switzerland, June 19-20, 2006.

Cavallo, Eduardo, and Jeffrey Frankel, 2005, "Does Openness to Trade Make Countries More Vulnerable to Sudden Stops, or Less? Using Gravity to Establish Causality" NBER Working Paper No. 10957, revised, Dec..

Chinn, Menzie, and Jeffrey Frankel, "Will the Euro Eventually Surpass the Dollar as Leading International Reserve Currency?" for NBER conference on G7 Current Account Imbalances: Sustainability and Adjustment, Newport, RI, June 1-2, 2005, edited by Richard Clarida. NBER Working Paper No. 11508, July 2005.

Cline, William, 2005, The United States as a Debtor Nation (Institute for International Economics, Washington DC).

Cooper, Richard, 2005, Living with Global Imbalances: A Contrarian View," Policy Briefs in International Economics, no. PB05-3, Institute for International Economics, Nov.

Dooley, Michael, David Folkerts-Landau, and Peter Garber, 2003, “An Essay on the Revived Bretton Woods System," NBER WP no 9971, Sept.

Dooley, Michael and Peter Garber, 2005, "Is it 1958 or 1968? Three Notes on the Longevity of the Revived Bretton Woods System," Brookings Panel on Economic Activity, 1, 2005, 19-204.

Feldstein, Martin, 2005, "Monetary Policy in a Changing International Environment: The Role of Global Capital Flows," NBER WP no. 11856, Dec.. 
Gourinchas, Pierre-Olivier and Helene Rey, 2005, "From World Bank to World Venture Capitalist: US External Adjustment and the Exorbitant Privilege," NBER conference on G7 Current Account Imbalances: Sustainability and Adjustment, Newport, RI, June 1-2, 2005. Edited by Richard Clarida (The University of Chicago Press, Chicago) forthcoming 2006.

Gros, Daniel, 2006, “Discrepancies in US Accounts Hide Black Hole,” Financial Times, June 14.

Hausmann, Ricardo, and Federico Sturzenegger, 2006, "Bad Accounting? The Missing Dark Matter in the Wealth of Nations," KSG Working Paper RWP06-003.

Ju, Jiandong, and Shang-Jin Wei, 2006, “A Solution to Two Paradoxes of International Capital Flows,” NBER Summer Institute, June.

Kindleberger, Charles, 1965, "Balance of Payments Deficits and the International Market for Liquidity,” Princeton Essays in International Finance No. 46, Princeton University, 1965.

Lane, Philip R. \& Milesi-Ferretti, Gian Maria, 2005. "A Global Perspective on External Positions," C.E.P.R. Discussion Papers 5234.

Obstfeld, Maurice, and Ken Rogoff, 2005, "Global Current Account Imbalances and Exchange Rate Adjustments," in William Brainard and George Perry (eds.), Brookings Papers on Economic Activity 1:67-146.

Obstfeld, Maurice, and Ken Rogoff, 2001, "Perspectives on OECD Capital Market Integration: Implications for U.S. Current Account Adjustment," in Federal Reserve Bank of Kansas City Global Economic Integration: Opportunities and Challenges, March, pp. 169-208.

Rogoff, Kenneth, 2004, “This Time It’s Not Different,” Newsweek International, Feb. 16.

Triffin, Robert, 1960, Gold and the Dollar Crisis. 